\title{
Streptozotocin, but Not Alloxan, Induces DNA Repair Synthesis in Mouse Pancreatic Islets in Vitro
}

\author{
S. Sandler and I. Swenne \\ Department of Medical Cell Biology, Uppsala University, Uppsala, Sweden
}

\begin{abstract}
Summary. In the present investigation, the abilities of streptozotocin and alloxan to induce DNA repair synthesis in isolated mouse pancreatic islets have been compared using an autoradiographic technique. Streptozotocin exposure in vitro induced a dose-dependent DNA repair synthesis, whereas no such effect was observed after alloxan treatment. The hydroxyl radical scavenger dimethyl urea and the poly(ADP-ribose) synthetase inhibitors nicotinamide and theophylline reduced
\end{abstract}

the streptozotocin-induced DNA repair. The results suggest that the initial events in streptozotocin-induced B cell injury are DNA damage and repair and that alloxan exerts its major cytotoxic effect by a different mechanism.

Key words: Alloxan, DNA repair, dimethyl urea, pancreatic islets, poly(ADP-ribose)synthetase, streptozotocin.
The precise mechanisms of the diabetogenic action of streptozotocin (STZ) and alloxan are not yet fully understood. It has been suggested recently that the primary effect of both these drugs on the endocrine pancreatic B cell is primarily induction of lesions of the DNA strand [1]. The injury induces DNA repair involving the activation of polyadenosine diphosphoribose (poly(ADP-rib))synthetase which uses cytosolic NAD as a substrate. It is thought that the lowered concentrations of NAD following this sequence of events may be the final step in the destruction of the B cell [1-3]. This hypothesis is further corroborated by the protective effect of compounds that inhibit nuclear poly(ADPrib)synthetase [4-7] against the depression of insulin biosynthesis caused by STZ and alloxan in vitro [3].

In the present study, we have used an autoradiographic technique to compare the abilities of STZ and alloxan to induce DNA repair synthesis in isolated pancreatic islets. In addition, the protective effects of both poly(ADP-rib)synthetase inhibitors and the hydroxyl radical scavenger dimethyl urea against STZ-induced DNA repair were evaluated.

\section{Materials and Methods}

\section{Chemicals}

Streptozotocin (lot 60, 273-5 U9889) was a gift from Dr. W.E.Dulin, Upjohn, Kalamazoo, Michigan, USA. Alloxan (2,4,5,6-tetraoxypy- rimidine) monohydrate and dimethyl urea were supplied by Sigma Chemicals, St.Louis, Missouri, USA. Collagenase was from Worthington Biochemicals, Freehold, New Jersey, USA and bovine albumin (fraction V) from Miles Laboratories, Slough, Bucks, UK. ${ }^{3} \mathrm{H}-$ thymidine (spec. act. $5 \mathrm{Ci} / \mathrm{mmol}$ ) was obtained from Amersham International, Bucks, UK. Emulsion Kodak NTB-2, developer Kodak D-19 and fixative F-24 were obtained from Kodak, Sollentuna, Sweden. Other chemicals of analytical grade were from E. Merck, Darmstadt, FRG.

\section{Islet Isolation and Incubation}

Islets of Langerhans were isolated by collagenase digestion [8] from overnight starved NMRI mice (Anticimex AB, Sollentuna, Sweden). Batches of 150 islets were pre-incubated in a Krebs-Ringer bicarbonate buffered medium [9] containing Hepes $(10 \mathrm{mmol} / \mathrm{l})$ and albumin ( $2 \mathrm{mg} / \mathrm{ml}$ ) subsequently referred to as $\mathrm{KRBH}$, for $30 \mathrm{~min}$ at $37^{\circ} \mathrm{C}$ in a humidified atmosphere of $5 \% \mathrm{CO}_{2}$ in air. In experiments involving STZ, KRBH (1 ml) supplemented with glucose $(5.6 \mathrm{mmol} / \mathrm{l})$ was used and $\mathrm{KRBH}(2 \mathrm{ml})$ containing either 2.8 or $16.7 \mathrm{mmol} / 1$ glucose was used in incubations with alloxan. Agents with a potentially protective effect against STZ were included in the media from the beginning of the pre-incubation period.

STZ was dissolved in cold citric acid buffer $(10 \mathrm{mmol} / 1, \mathrm{pH} 4.5)$ and alloxan in KRBH containing glucose $(2.8 \mathrm{mmol} / \mathrm{l})<1 \mathrm{~min}$ before addition to the incubation media. In control experiments buffer alone was added to the media. The incubations were continued for a further $30 \mathrm{~min}$ at $20^{\circ} \mathrm{C}$ in air and subsequently terminated by rinsing the islets in the appropriate $\mathrm{KRBH}$ medium.

Islets were then incubated in $5 \mathrm{ml} \mathrm{KRBH}$ with glucose $(5.6 \mathrm{mmol} / \mathrm{l})$ and ${ }^{3} \mathrm{H}$-thymidine $(10 \mu \mathrm{Ci} / \mathrm{ml})$ for $120 \mathrm{~min}$ at $37^{\circ} \mathrm{C}$ in a humidified atmosphere of $5 \% \mathrm{CO}_{2}$ in air for determination of DNA repair synthesis. After incubation the islets were washed in non-radioactive medium and fixed in Bouin's solution. 


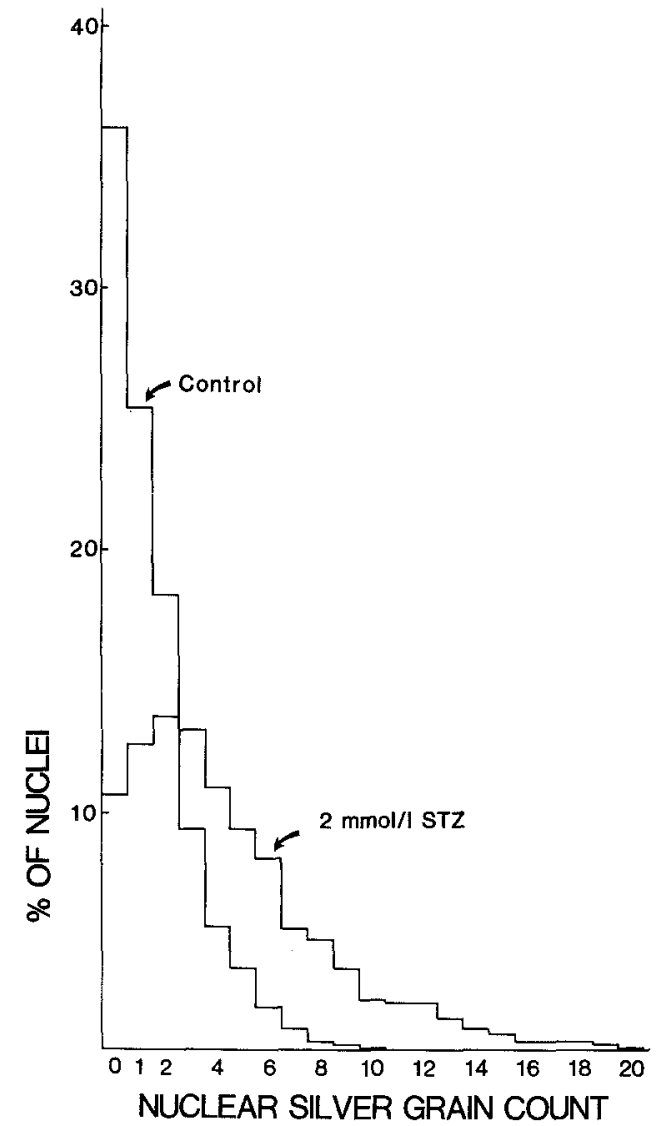

Fig. 1. Autoradiographic nuclear grain count distribution of islets exposed to streptozotocin. After exposure to STZ, the islets were incubated with ${ }^{3} \mathrm{H}$-thymidine and autoradiographed as described in Materials and Methods. The number of silver grains overlying each islet cell nucleus was scored in at least 2000 cells in each group. The numbers of nuclei with a certain grain count is expressed as a percentage of the total number of counted cells

Table 1. DNA repair synthesis of islets of Langerhans after exposure to streptozotocin in vitro

\begin{tabular}{llllll}
\hline \multicolumn{5}{c}{ Streptozotocin $(\mathrm{mmol} / \mathrm{l})$} & \\
\cline { 2 - 6 } & 0 & 0.55 & 1.1 & 2.2 & 4.4 \\
\hline $\begin{array}{l}\text { Nuclear } \\
\text { grain } \\
\text { count }\end{array}$ & $1.67 \pm 0.07$ & $2.19 \pm 0.20^{\mathrm{a}}$ & $3.43 \pm 0.32^{\mathrm{b}}$ & $4.39 \pm 0.30^{\mathrm{b}}$ & $3.29 \pm 0.26^{\mathrm{b}}$ \\
\hline
\end{tabular}

The values are given as mean \pm SEM for five preparations. Significance of difference between control and STZ treated islets ${ }^{\mathrm{a}} p<0.05$; ${ }^{\mathrm{b}} p<0.001$

\section{Histological Examination and Autoradiography}

The fixed islet specimens were embedded in paraffin, sectioned at $7 \mu \mathrm{m}$ and mounted on glass slides. The slides were dipped in Kodak NTB-2 emulsion, carefully desiccated and exposed for 9 weeks at $4^{\circ} \mathrm{C}$. Slides were then developed in Kodak D-19 at $20^{\circ} \mathrm{C}$ for 6 min, fixed in Kodak F-24 for $10 \mathrm{~min}$ and finally stained with haematoxylin.

To estimate the islet cell DNA repair synthesis, the nuclear grain count (i.e. the number of silver grains directly overlying each islet cell nucleus) was counted in at least 200 islet cells in each preparation. The distribution of nuclear grain counts and the mean nuclear grain count was calculated, the latter being used as an index of the DNA repair synthesis.
The grain count per unit area not overlying the tissue sections (i.e. the background grain count) was similar in all experimental groups. Furthermore, the background grain count did not differ from the grain count per unit area of the emulsion overlying the islet sections in the control groups, which had been incubated in the absence of STZ and alloxan. The few islet cells undergoing DNA replication showed heavily labelled nuclei and were easily distinguished from the rest of the islet cells. The replicatory activity was generally low $(<0.5 \%)$ both in the islets exposed to STZ or alloxan and in the controls.

In addition, the degree of islet fragmentation and islet cell pycnosis was estimated in each histological preparation. Islet sections with pycnotic nuclei and fragmented tissue architecture had a grain count per unit area similar to the background grain count, irrespective of the grain count obtained from apparently viable cells in the same preparation. The pycnotic portions of the islet sections were therefore excluded from the estimations of mean nuclear grain counts.

\section{Results}

\section{Effects of Streptozotocin on Islet DNA Repair}

Exposure of isolated islets to STZ induced a dosedependent DNA repair synthesis, as indicated by an increased silver grain count (Table 1). The histogram describing the distribution of grain counts (Fig. 1) of individual nuclei showed a single discrete peak in both control and STZ-treated islets with a marked shift towards higher counts in the latter group. The highest rate of DNA repair synthesis was found in islets exposed to $2.2 \mathrm{mmol} / 1 \mathrm{STZ}$ (Table 1). At this concentration, small areas of islet nuclear pycnosis occasionally could be observed, a finding not present at the lower concentrations of STZ or in the control groups. At $4.4 \mathrm{mmol} / 1 \mathrm{STZ}$, all experimental preparations showed nuclear pycnosis, in some sections up to $25 \%$ of the cells.

\section{Effects of Alloxan on Islet DNA Repair}

Alloxan exposure did not induce DNA repair synthesis in isolated islets (Table 2). Over the alloxan concentration range $0.5-2.0 \mathrm{mmol} / 1$ there was no increase in the nuclear grain count. At $4.0 \mathrm{mmol} / 1$ alloxan, all the islet cell nuclei were pycnotic and the tissue had begun to disintegrate. At the lower alloxan concentrations there appeared to be a dose-dependent increase of nuclear pycnosis which comprised at the most $50 \%$ of the islets cell nuclei.

\section{Effects of Poly(ADP-ribose)synthetase Inhibitors and Dimethyl Urea on Streptozotocin-Induced DNA Repair}

The poly(ADP-rib)synthetase inhibitors nicotinamide $(6.1 \mathrm{mmol} / \mathrm{l})$ and theophylline $(5 \mathrm{mmol} / \mathrm{l})$ both reduced STZ induced DNA repair (Table 3 ). At the concentrations used nicotinamide reduced DNA repair to levels similar to those observed in the control group, whereas theophylline did not cause a notable inhibition. Dimethyl urea $(68 \mathrm{mmol} / \mathrm{l})$ also caused a partial inhibition of STZ-induced DNA repair. 
Table 2. DNA repair synthesis of islets of Langerhans after exposure to alloxan in vitro

\begin{tabular}{lllllll}
\hline & \multicolumn{2}{l}{ Alloxan $(\mathrm{mmol} / \mathrm{l})$} & & & & \\
\cline { 2 - 6 } & 0 & 0.5 & 1.0 & 2.0 & 4.0 & 2.0 \\
\hline Glucose (mmol/1) & 2.8 & 2.8 & 2.8 & 2.8 & 2.8 & 16.7 \\
Nuclear grain count & $\mathbf{1 . 2 6 \pm 0 . 0 7 ( 6 )}$ & $1.37 \pm 0.09(6)$ & $1.49 \pm 0.12(4)$ & $1.35 \pm 0.13(4)$ & $-(6)^{\mathrm{a}}$ & $1.26 \pm 0.07(6)$ \\
\hline
\end{tabular}

Values for nuclear grain count are given as mean \pm SEM with number of observations in parentheses.

a Nuclear grain count not possible due to pycnosis

Table 3. DNA repair synthesis of islets of Langerhans after exposure to streptozotocin and protective agents in vitro

\begin{tabular}{|c|c|c|c|c|c|}
\hline & \multicolumn{5}{|c|}{ Streptozotocin $(\mathrm{mmol} / \mathrm{l})$} \\
\hline $\begin{array}{l}\text { Protective agent } \\
(\mathrm{mmol} / \mathrm{l})\end{array}$ & 0 & 0 & $\begin{array}{l}\text { nicotinamide } \\
(6.1)\end{array}$ & $\begin{array}{l}\text { theophylline } \\
(5.0)\end{array}$ & $\begin{array}{l}\text { dimethyl urea } \\
(68)\end{array}$ \\
\hline Nuclear grain count & $1.89 \pm 0.15$ & $4.99 \pm 0.22^{b}$ & $2.41 \pm 0.25^{\mathrm{e}}$ & $3.54 \pm 0.32^{\mathrm{a}, \mathrm{d}}$ & $3.83 \pm 0.32^{\mathrm{b}, \mathrm{c}}$ \\
\hline
\end{tabular}

Values are given as mean \pm SEM for five observations. Significance of difference between control and STZ exposed islets

${ }^{\mathrm{a}} p<0.01 ;{ }^{\mathrm{b}} p<0.001$ and between islets treated with STZ only and those treated with $\mathrm{STZ}$ and a potentially protective agent ${ }^{\mathrm{c}} p<0.05$;

${ }^{\mathrm{d}} p<0.01 ; \mathrm{e} p<0.001$

\section{Discussion}

There are several advantages to the use of autoradiographic techniques in the estimation of DNA repair synthesis [10]. Firstly, both the background grain count and the grain count of the control tissue can be compared to establish that there is no significant repair during control conditions. Secondly, during the microscopical examination of the autoradiographs the few cells undergoing DNA replication can be identified easily and excluded from the calculations of mean grain counts, provided that the correct exposure time and development conditions are chosen. This procedure increases the sensitivity of the method thus making it possible to detect low levels of DNA repair. Indeed, if the ${ }^{3} \mathrm{H}$-thymidine incorporation were measured after STZ treatment in trichloroacetic acid precipitable islet material, most of the isotope recovered would be derived from replicating cells (Swenne and Sandler, unpublished results). Finally, the morphological examination allows a general assessment of the viability of the tissue to be made.

The distribution of grain counts following STZtreatment suggests that the majority of islet cells were affected by the drug. The present demonstration of an active DNA repair process in combination with the previously observed DNA fragmentation and poly(ADPrib) formation after islet STZ exposure in vitro $[2,3]$ strongly supports the view that STZ may act primarily by damaging the islet DNA. In further support of this hypothesis both nicotinamide and theophylline completely or partially inhibited STZ-induced DNA repair. Interestingly, the degree of inhibition correlated well with the degree of metabolic deterioration in the presence of these drugs as observed in other experiments [11]. Furthermore, it was found that the hydroxyl radical scavenger dimethyl urea offered partial protection against STZ-induced DNA repair. A free radical mediated B-cell cytotoxicity of STZ has indeed been suggested [12-15] although free radical scavengers do not always protect the B cell against STZ-induced injuries $[3,16]$.

It was not possible to demonstrate an induction of DNA repair by alloxan in isolated mouse islets. From the present data it cannot be excluded that alloxan itself might affect the uptake of ${ }^{3} \mathrm{H}$-thymidine, which could also be the case after exposing islets to dimethyl urea or nicotinamide. Previous observations, however, indicate that theophylline is without effect on ${ }^{3} \mathrm{H}$-uptake [17]. Alternatively, alloxan might damage the DNA repair mechanism itself, resulting in an apparently lowered DNA repair. The morphological findings, nevertheless, suggest that alloxan had a prompt and pronounced effect on islet cell viability which could indicate that the crucial site of B cell cytotoxicity of alloxan is different from that of STZ. In support of this view, we have failed to observe a protective effect of nicotinamide against the alloxan-induced depression of glucose stimulated proinsulin and insulin biosynthesis and islet oxygen uptake in vitro [18]. Furthermore, nicotinamide which protects against STZ diabetogenecity in vivo $[19,20]$ was ineffective in preventing hyperglycaemia when administered similarly in conjunction with alloxan [18]. There is, indeed, evidence to suggest that the primary site of alloxan action may be on either the $\mathrm{B}$ cell mitochondria $[21,22]$ or the cell membrane [23, 24]. Although, poly(ADP-rib)synthetase activation has been demonstrated in islets after alloxan exposure [3] it does not appear to be the major event leading to $\mathrm{B}$ cell destruction.

The increased understanding of the molecular mechanism for STZ-induced B cell damage has thus far not accounted for the remarkable specificity of the drug 
for the B cell. A preferential uptake of the drug due to the glucose moiety of the molecule has been put forward to explain the B-cell cytotoxicity [25-27]. An especially high sensitivity of the B cell to NAD depletion is also a possible explanation but one which requires further experimental support. In the case of alloxan, a selective uptake in conjunction with low intracellular concentrations of glutathione peroxidase, an enzyme scavenger of oxygen radicals, may explain the high $\mathrm{B}$ cell susceptibility [28, 29].

Acknowledgements. We thank Drs A.Andersson and C.Hellerström for valuable advice during the course of this work. We are grateful to A.-B.Andersson, K.Claesson, A. Snellman and P. Wentzel for secretarial and technical assistance. This work was supported by grants from the Swedish Medical Research Council (12X-109), the Swedish Diabetes Association, Uppsala University, Stiftelsen Clas Groschinsky minnesfond, the Swedish Society for Medical Sciences and Syskonen Svenssons minnesfond.

\section{References}

1. Okamoto H (1981) Regulation of proinsulin synthesis in pancreatic islets and a new aspect to insulin-dependent diabetes. Mol Cell Biochem 37: 43-61

2. Yamamoto $H$, Uchigata $Y$, Okamoto $H$ (1981) Streptozotocin and alloxan induce DNA strand breaks and poly(ADP-ribose)synthetase in pancreatic islets. Nature 294: 284-286

3. Uchigata Y, Yamamoto H, Kawamura A, Okamoto H (1982) Protection by superoxide dismutase, catalase and poly(ADPribose)synthetase inhibitors against alloxan- and streptozotocininduced islet DNA strand breaks and against the inhibition of proinsulin biosynthesis. J Biol Chem 257: 6084-6088

4. Claycombe WC (1976) Poly(adenosine diphosphate ribose) polymerase activity and nicotinamide adenine dinucleotide in differentiating cardiac muscle. Biochem J 154: 387-393

5. Smulson ME, Schein P, Mullins Jr DW, Sudhakar S (1977) A putative role for nicotinamide adenine dinucleotide-promoted nuclear protein modification in the antitumor activity of $\mathrm{N}$-methylN-nitrosourea. Canc Res 37: 3006-3012

6. Levi V, Jacobson EL, Jacobson MK (1978) Inhibition of poly(ADP-ribose)polymerase by methylated xanthines and cytokinins. FEBS Lett 88: 144-146

7. Skidmore CJ, Davies MI, Goodwin PM, Halldorson H, Lewis PJ, Shall S, Ziaèe A-A (1979) The involvement of poly(ADP-ribose)polymerase in the degradation of NAD caused by $\gamma$-radiation and N-methyl-N-Nitrosurea. Eur J Biochem 101: 135-142

8. Howell SL, Taylor KW (1968) Potassium ions and the secretion of insulin by islets of Langerhans incubated in vitro. Biochem $\mathrm{J} 108$ : $17-24$

9. Krebs HA, Henseleit K (1932) Untersuchungen über die Harnstoffbildung im Tierkörper. Hoppe-Seylers Z Physiol Chem 210: 33-66

10. Hanawalt PC, Cooper PK, Ganesan AK, Smith CA (1979) DNA repair in bacteria and mammalian cells. Ann Rev Biochem 48: $783-836$

11. Sandler S, Welsh M (1982) In vitro effects of streptozotocin (SZ) on (pro)insulin biosynthesis, contents of adenine and pyridine nucleotides and oxygen uptake in mouse pancreatic islets. Acta Endocrinol 100 Supp1 247: 54 (Abstract)
12. Robbins MJ, Sharp RA, Slonim AE, Burr IM (1980) Protection against streptozotocin-induced diabetes by superoxide dismutase. Diabetologia 18: 55-58

13. Marklund S, Grankvist K (1980) Polyethyleneglycol-superoxide dismutase (PEG-SOD) protect against streptozotocin-induced diabetes in mice. Acta Endocrionol 98 Suppl 245: 43 (Abstract)

14. Gandy SM, Buse MG, Crouch RK (1982) Protective role of superoxide dismutase against diabetogenic drugs. J Clin Invest 70 : 650-658

15. Sandler S, Andersson A (1982) The partial protective effect of the hydroxyl radical scavenger dimethyl urea on streptozotocin-induced diabetes in the mouse in vivo and in vitro. Diabetologia 23: 374-378

16. Gold G, Manning M, Heldt A, Nowlain R, Pettit JR, Grodsky GM (1981) Diabetes induced with multiple subdiabetogenic doses of streptozotocin. Lack of protection by exogenous superoxide dismutase. Diabetes 30: 634-638

17. Swenne I (1982) Effects of cyclic AMP on DNA replication and protein biosynthesis in fetal rat islets of Langerhans maintained in tissue culture. Bioscience Reports 2: 867-876

18. Sandler S, Welsh M (1982) Effects of nicotinamide on alloxan and streptozotocin induced mouse pancreatic B cell cytotoxicity in vivo and in vitro. Diabetologia 23: 197 (Abstract)

19. Schein PS, Cooney DA, Vernon ML (1967) The use of nicotinamide to modify the toxicity of streptozotocin diabetes without loss of antitumor activity. Canc Res $27: 2324-2332$

20. Rerup C, Tarding F (1969) Streptozotocin- and alloxan-diabetes in mice. Eur J Pharm 7: 89-96

21. Borg LAH, Eide SJ, Andersson A, Hellerström C (1979) Effects in vitro of alloxan on glucose metabolism of mouse pancreatic B-cells. Biochem J 182: 797-802

22. Boquist L (1980) A new hypothesis for alloxan diabetes. Acta Path Microbiol Scand Sect A 88: 201-209

23. Cooperstein SJ, Watkins D (1981) Action of toxic drugs on islet cells. In: Cooperstein SJ, Watkins D (eds) The islets of Langerhans. Academic Press, New York, pp 387-425

24. Grankvist K (1981) Mechanisms of alloxan diabetogenicity. Thesis. Umeå University Medical Dissertations 72: 1-38

25. Andersson T, Schein PS, McMenamin MG, Cooney DA (1974) Streptozotocin diabetes. Correlation with extent of depression of pancreatic islet nicotinamide adenine dinucleotide. J Clin Invest 54: 672-677

26. Gunnarsson R, Berne C, Hellerström C (1974) Cytotoxic effects of streptozotocin and N-nitrosomethylurea on the pancreatic B cells with special regard to the role of nicotinamide-adenine dinucleotide. Biochem J 140: 487-494

27. Karunanayake EH, Baker JRJ, Christian RA, Hearse DJ, Mellows $\mathrm{G}$ (1976) Autoradiographic study of the distribution and cellular uptake of $\left({ }^{14} \mathrm{C}\right)$-streptozotocin in the rat. Diabetologia 12: 123-128

28. Malaisse WJ, Malaisse-Lagae F, Sener A, Pipeleers DG (1982) Determinants of the selective toxicity of alloxan to the pancreatic B-cell. Proc Natl Acad Sci USA 79: 927-930

29. Gorus FK, Malaisse WJ, Pipeleers DG (1982) Selective uptake of alloxan by pancreatic B-cells. Biochem J 208: 513-515

Received: 21 February 1983

and in revised form: 27 June 1983

Dr. S. Sandler

Department of Medical Cell Biology

Biomedicum

P.O. Box 571

S-75123 Uppsala

Sweden 